Int. J. Electrochem. Sci., 14 (2019) 10943 - 10955

International Journal of

ELECTROCHEMICAL

SCIENCE

$\underline{\text { WWW.electrochemsci.org }}$

\title{
Electrochemical Degradation of Acetaminophen in the Presence of Different Redox Mediator Systems
}

\author{
Kuo-Lin Huang *, Shi-Jie Huang \\ Department of Environmental Science and Engineering, National Pingtung University of Science and \\ Technology, Pingtung 91201, Taiwan (ROC) \\ *E-mail: huangkl@ mail.npust.edu.tw
}

doi: $10.20964 / 2019.12 .80$

Received: 12 August 2019 / Accepted: 8 October 2019 / Published: 29 October 2019

This study focuses on the electrochemical degradation of acetaminophen (AP) in the presence of individual redox mediators. The oxidation peaks of $\mathrm{Fe}(\mathrm{II}), \mathrm{Ag}(\mathrm{I})$, and sulfate were detected on a Windsor boron-dopped diamond (BDD) electrode in $1 \mathrm{M} \mathrm{Na}_{2} \mathrm{SO}_{4}$. The AP degradation performance using a single mediator was in the following order: $\mathrm{Ce}(\mathrm{IV})$ (from $\left.\mathrm{Ce}\left(\mathrm{SO}_{4}\right)_{2}\right)>\mathrm{Fe}$ (III) (from $\mathrm{Fe}\left(\mathrm{NO}_{3}\right)_{3}$ or $\left.\mathrm{FeCl}_{3}\right)>\mathrm{Co}$ (II) (from $\mathrm{CoCl}_{2}$ ) $\approx \mathrm{Ag}(\mathrm{I})$ (from $\mathrm{AgNO}_{3}$ ). $p$-BQ due to AP degradation was observed in $1 \mathrm{M} \mathrm{Na}_{2} \mathrm{SO}_{4}$ in the presence of $\mathrm{Ce}(\mathrm{IV})$ and $\mathrm{Fe}(\mathrm{III})$, while the former exhibited more and faster $p$-benzoquinone ( $p$-BQ) generation than the latter. In the presence of individual mediators in $1 \mathrm{M} \mathrm{Na} \mathrm{SO}_{4}$ or $\mathrm{NaNO}_{3}$, the performance of electrochemical AP degradation, $p$-BQ removal, and TOC mineralization on a Diachem BDD anode occurred in the following order: $\mathrm{Fe}(\mathrm{III})>\mathrm{Ce}(\mathrm{IV})>\mathrm{Fe}(\mathrm{II}) \approx \mathrm{Co}(\mathrm{II})>\operatorname{Ag}(\mathrm{I})$, but the performance decreased when replacing $\mathrm{Na}_{2} \mathrm{SO}_{4}$ with $\mathrm{NaNO}_{3}$ as the electrolyte. The $\mathrm{Cl}_{2} / \mathrm{Cl}^{-}$redox mediator could also enhance AP degradation and TOC mineralization. The apparent pseudo first-order rate constants for AP electrochemical degradation in these solutions ranged from $2.92 \times 10^{-4}-4.34 \times 10^{-2}$ $1 / \mathrm{s}$. An Fe(III) dosage of $100 \mathrm{ppm}(\mathrm{Fe}(\mathrm{III}) / \mathrm{AP}$ mole ratio $=2.7)$ at $0.25 \mathrm{~A} / \mathrm{cm}^{2}$ is suggested for this electrochemical process although $\mathrm{Fe}$ (III) dosage in the range of 50-500 ppm could be considered. Fe(III) has good potential for use in the elctrochemical advanced oxidation process (EAOP) to significantly improve organic pollutant degradation performance.

Keywords: electrochemical degradation; acetaminophen (AP); $p$-benzoquinone ( $p$-BQ); redox mediator; boron-doped diamond (BDD) electrode

\section{FULL TEXT}

(C) 2019 The Authors. Published by ESG (www.electrochemsci.org). This article is an open access article distributed under the terms and conditions of the Creative Commons Attribution license (http://creativecommons.org/licenses/by/4.0/). 